\title{
Információforrások használatának gyakorisága és információs rendszerek az élelmiszeripari társas vállalkozásban - felmérés a Dél-Alföld régió élelmiszeripari társas vállalkozásainak vezetői körében
}

\author{
György Hampel ${ }^{1}$
}

\section{N F O}

Received 1 April 2010

Accepted 19 May 2010

Available on-line 31 May 2010

Responsible Editor: K. Rajkai

\section{Keywords:}

Hungary's Southern Great Plain Region, food industry

enterprises, information source, information systems, decision

\section{N F O}

Beérkezés 2010 Április 1. Elfogadás 2010 Május 19. On-line elérés 2010 Május 31. Felelős szerkesztő: Rajkai K

\section{Kulcsszavak:}

Dél-Alföld, élelmiszeripari társas vállalkozások, információforrás, információs rendszer, döntés

\begin{abstract}
A B S T R A C T
My research conducted in Hungary's Southern Great Plain Region was aimed at the information source used for decision making by the executives of food industry enterprises and at the main characteristics and capabilities of the information systems of the firms. The data necessary for the research was gathered mostly with questionnaires and with interviews in the case of some bigger enterprises. Based on the results of the surveying, the executives rely consistently on the data and information from the different modules of their internal reporting systems. When making decisions, they also build upon information from other people (managers, employees, owners, suppliers, customers) to the same extent. The media is also a frequently used information source. The most important source of information is directly linked to the information system modules closely related to production of the enterprise. The use of information systems to support decision making or forecasting is not typical in a food industry firm.
\end{abstract}

\section{Ö S S Z E F O G L A L Ó}

A Dél-Alföldön végzett kutatásom az élelmiszeripari társas vállalkozások vezetői által, a múködés különböző területein hozott, illetve különböző tárgyú döntésekhez használt információforrásokra, valamint a vállalkozásokban használt információs rendszerek fó jellemzőire, képességeire irányult. A kutatáshoz szükséges adatok beszerzése kérdőívekkel, illetve néhány nagyobb vállalkozás esetében interjúk segítségével történt meg. A kutatás eredményei alapján a vezetők következetesen a belső beszámoló rendszer különböző részeiből származó adatokra, információkra támaszkodnak. Emellett ugyanilyen mértékben hozzák meg döntéseiket más emberektől (nagyobb részben vezetőktől, beosztottaktól, kisebb részben a tulajdonosoktól, szállítóktól és vevőktől) származó információkra alapozva. A média szintén a gyakrabban használt információforrások közé tartozik. A legfontosabb információforrást közvetlenül a szervezet információs rendszerének termeléssel kapcsolatos, vagy ahhoz szorosabban kötődő része képezi. Olyan információs rendszerek használata, amelyek kifejezetten a döntések meghozatalának támogatására, elörejelzések készítésére vannak felkészítve, az élelmiszeripari vállalkozásokban nem jellemző.

\section{Bevezetés}

A gazdasági szervezeteknek mindig szükségük van információra, ez az információfüggőség müködésük valamennyi területére kihat. (Berde et al., 2003) A mai gyorsan változó környezetben a megfelelő időben rendelkezésre álló effektív üzleti információk nem csak a sikerhez, hanem a túléléshez is szükségesek. (Lönnqvist, Pirttimäki, 2006) A hagyományos erőforrások mellett már több évtizede, új erőforrásként jelen van az adat és az információ. Az adatok megfelelő formába (azaz információvá) alakítása nélkül a vállalati vezetés nem hozhat jó döntéseket. (Hannon, 2005) Az információnak a döntéshozatal minden fázisában meghatározó a szerepe: a döntési folyamatot információ-felvétel indítja, ezt követi az információk gyüjtés és elemzése, ami lehetővé teszi a döntési helyzet azonosítását. A célok kitüzése és a cselekvési változatok kidolgozása is mind-mind információk alapján történik. (Enyediné, 1997)

\footnotetext{
${ }^{1}$ György Hampel

Szegedi Tudományegyetem Mérnöki Kar

hampel@mk.u-szeged.hu
} 
Az információ olyan mértékben szövi át a vállalkozások müködését, hogy a vállalkozást információ-feldolgozó szervezetként is fel lehet fogni. Az információ kezelésére szakosodott alrendszer a vállalkozás minden érintettjével (fogyasztók, szállítók, versenytársak, vállalati termékek, adatok a gazdaság egészéről stb.) kapcsolatban áll. Az összegyüjtött adatok a feldolgozás során alakulnak át információvá, amikor is a feldolgozáson átesve érdemben használhatóvá vállnak a döntéshozó számára, aki értelmezi az információt és ennek alapján döntéseket hoz (Chikán, 2005).

Fontos, hogy a megfelelő információ, a megfelelő felhasználónak, megfelelő időben, megfelelő formában, megfelelő minőségben, megfelelő áron és megfelelő helyen álljon rendelkezésre (Kiszl, 2005). A döntésekhez felhasznált információk származhatnak a vállalkozáson belülröl, annak belső információs rendszeréből, vagy vállalaton kívüli adatbázisokból. A vezetői döntéshez szükséges adatok egyrészt lehetnek olyan adatok, amelyek a vállalkozás irányításához rendszeresen szükségesek; ezeket az adatokat a pénzügyi, számviteli, statisztikai nyilvántartás, a cég belső beszámoló rendszere folyamatosan kimutatja. Másrészt vannak olyan adatok, információk, amelyekre a vezetőknek csak időnként, egy-egy üzleti döntés megalapozásához van szükségük. A vállalkozáson belülröl és a külső környezetből származó információk és azok forrásai nagyon sokfélék lehetnek. Például Tayor és Farrel szerint az információk és forrásaik lehetséges csoportjai: cégszintű információk (kézikönyvek, piackutatási jelentések), piaci információk (sajtó, kereskedelmi kiadványok, on-line tájékoztatók), termékinformációk (üzleti rendezvények kiadványai, statisztikai kiadványok, belső kiadványok), gazdasági információk (hivatalos média, tudományos munkák, előrejelzések, elemzések), statisztikai információk (a cég adatgyüjtései, belső adatok, versenytársak adatai), valamint menedzsment információk (pénzügyi hatóságok kiadványai, intézmények kiadványai, tőzsdepiaci információk) (Taylor, Farrel, 1995). Vannak, akik szerint minden, ami a vezetöi irodába beérkezik, információnak tekinthetö (Bögel et al., 2002).

Az információrobbanás következtében a rendelkezésre álló információ sokszor használhatatlan és kezelhetetlen a gazdasági élet szereplői számára. Az információ túlkínálat kezelésének egyik hatékony módja a modern, számítógép által támogatott információs rendszer létrehozása és múködtetése; egy olyan rendszeré, amely több információt nyel el, mint amennyit létrehoz. (Simon, 1982) A vezetők információellátásának megszervezésekor nem szabad elárasztani a vezetőt mindazzal, amire egy információs rendszer képes. Pontosan kell felmérni, hogy a vezetés milyen információkra tart igényt és mi az, ami valóban szükséges neki (Dobay, 2003) .

A megfelelő tudású és megfelelő módon alkalmazott információs rendszer biztosíthatja a vállalkozás versenyképességének megőrzését (Porter, Millar, 1985). A vállalkozás információszükségletének legtöbb feladatát kielégítő számítógépes programgyüjteményről van szó, amely ellátja a közép- és felső vezetést azokkal az információkkal, amelyek ahhoz szükségesek, hogy ellenőrizni és irányítani tudják azokat a tevékenységeket, amelyekért felelősek (Wallace, Kremzar, 2006). Ma sokféle technológiát felvonultató és számos szolgáltatást nyújtó rendszer él egymás mellett a különböző vállalkozásokban (Kövesi, 2007). Vezetői szempontból kiemelkedő fontosságú a kötelezően elöírt, jogszabályok alapján müködő, múlt- és jelenbeli tényeket közlő pénzügyi számvitel, illetve a vezetők számára jövőbeli várható értékeket és külső információkat is tartalmazó, a tervezést, döntést és ellenőrzést hatékonyabban támogató vezetői számvitel információi (Kardos et al., 2007). Az információs rendszerek osztályozása, csoportba sorolása az alkalmazott technológiák, nyújtott szolgáltatások sokszínüsége miatt sokszor nehéz - általában beszélhetünk végrehajtási tevékenységet támogató, vezetői munkát támogató, illetve egyéb átfedő rendszerekről.

Az élelmiszeripar a magyar nemzetgazdaságnak ma is jelentős ágazata, annak ellenére, hogy az iparon belüli súlya az elmúlt évtizedek során fokozatosan csökkent. A mezőgazdasági termékek iránt támasztott kereslete, a hazai élelmiszer-ellátásban és az exportban, valamint a foglalkoztatásban betöltött szerepe alapján az élelmiszeripar stratégiai fontossága napjainkban sem vitatható. Kutatásomat a Dél-Alföld régió három megyéjében, Bács-Kiskun, Békés és Csongrád megyékben, az élelmiszeripari társas vállalkozások vezetőinek körében végeztem. Azt vizsgáltam, hogy a vállalkozások vezetői egyes belső és külső információforrásokra milyen gyakorisággal támaszkodnak, illetve információs rendszereik milyen szolgáltatásokat nyújtanak. 


\section{Módszertan}

A kutatás keretében vizsgált információforrás csoportok és azon belül az információforrások a következők voltak:

- Emberek: tulajdonosok, vezetők, beosztottak, szállítók, vevők;

- Üzleti környezet: bankok, versenytársak, egyéb cégek;

- Kormányzati szervek: országos, regionális és helyi szervek;

- Civil szervezetek: országos, regionális, valamint helyi szervezetek;

- Belső beszámoló rendszerek: döntéstámogató rendszerek, tervezés, pénzügy és számvitel, kontrolling, beszerzés, értékesítés, termelés, minőségbiztosítás, készletgazdálkodás, humánerőforrás-gazdálkodás, egyéb belső rendszer;

- Statisztikai szervezetek: évkönyvek, havi kiadványok, időszaki közlemények, módszertani kiadványok, elemző kiadványok;

- Kutatóintézetek: az MTA szervezetei, felsőoktatás intézmények, gazdaságkutató intézetek, saját kutatás, egyéb kutatóintézetek;

- Szakmai körök: hírlevelek, fórumok, egyéb szakmai körök;

- Média: televízió, rádió, szakmai lapok, nem szakmai lapok, internet (Szabó, 2001) (Lehota et al., 2001);

A vezetők döntéseiket különböző „müködési területeken” hozzák, illetve döntéseik különböző tárgyúak lehetnek (Hanyecz, 1994). A vállalati müködés fő területei: pénzügyek, termelés és szolgáltatás, marketing és kereskedelem, valamint termelési tényezők. A döntések irányulhatnak a gazdálkodás valamely területére, így piaci-gazdasági, müszaki és szervezési döntésekről beszélhetünk.

A vizsgálat tárgyát képezte, hogy az élelmiszeripari társas vállalkozások alkalmaznak-e valamilyen hagyományos, vagy integrált vállalatirányítási információs rendszert, vagy azok egy részrendszerét, továbbá, hogy az alkalmazott rendszerek milyen feladatok ellátására alkalmasak, rendelkeznek-e a jelen helyzet elemzéséhez, vagy elörejelzések készítéséhez alkalmas eszközökkel.

A kutatáshoz szükséges adatok beszerzése kérdőívekkel, illetve néhány nagyobb vállalkozás esetében személyesen, interjúk segítségével történt meg.

Az elvégzett vizsgálatok:

- Cronbach-alfa tesztet végeztem annak megállapítására, hogy a vezetők által a kérdőív kérdéseire adott válaszok konzisztensnek tekinthetők-e.

- Meghatároztam, hogy müködési területenként és a döntés tárgya szerint milyen gyakorisággal használják a vezetők az egyes információforrásokat, illetve az azokból képzett információforrás csoportokat.

- Klaszter analízist végeztem, melynek során megvizsgáltam, hogy a vezetők válaszaik alapján milyen hasonló információforrás használatot mutató csoportokba sorolhatók be.

\section{Eredmények}

A részvétel önkéntes volta következtében a megkeresett 250 élelmiszeripari társas vállalkozásból 27 vállalkozás vezetői, összesen 59 -en vettek részt. A vezetők közel fele-fele arányban tartoztak a felsővezető (47\%) és a középvezető (53\%) szinthez. Szintén közel azonos volt a korlátolt felelősségü társaságból $(47 \%)$ és a részvénytársaságból származó vezetők $(51 \%)$ aránya. A kitöltött kérdőívek maradék 3\%-a szövetkezeti vezetőtől érkezett vissza. Az éves árbevétel szerinti megoszlás a következő volt: a vezetők 47\%-a 51-1000 millió forint éves árbevétellel rendelkező cégnél, 53\%-a 1000 millió forint feletti árbevétellel rendelkező cégnél dolgozott. A legtöbb vezető olyan vállalatot vezetett, ahol a foglalkoztatottak száma 50-99 fö (29\%), 100-149 fö (17\%), 500-999 fö (12\%), vagy 250-299 fő (10\%) volt. Ezek a vezetők a felmérés résztvevőinek kétharmadát tették ki. Az 1000 főnél több dolgozót foglalkoztató cégek aránya a felmérésben 7\% volt. A válaszok tizenhárom féle élelmiszeripari fö tevékenységet végző vállalkozástól érkeztek. Elsősorban azok a vezetők mutattak kitöltési hajlandóságot, akiknek a cége húsfeldolgozással és tartósítással (19\%), tejtermékek gyártásával (17\%), kenyér és friss tésztafélék gyártásával (12\%), baromfihús feldolgozásával és 
tartósításával (10\%), vagy máshova nem sorolt egyéb élelmiszer gyártásával foglalkoztak (8\%). Ezek a vezetők töltötték ki a kérdőívek kétharmadát.

A kérdőív információforrások használatának gyakoriságát felmérő részénél Cronbach-alfa tesztet végeztem (1. táblázat) annak megállapítása érdekében, hogy a vezetők válaszai nem ellentmondásosak-e. A vezetők válaszai a hétféle vizsgálati szempont közül hat esetben konzisztensek, míg egy esetben - piac-gazdasági tárgyú döntéseknél - ellentmondásosnak tünnek e teszt alapján. Ebben az esetben a vizsgált 48 információforrásból tizenkettőt kellene figyelmen kívül hagyni ahhoz, hogy a Cronbach-alfa értéke 0,7 feletti, azaz konzisztens legyen. Így további vizsgálat esetén a vizsgált minta elemszámának növelése, új kérdőíves felmérések készítése jelenthet megoldást.

1. táblázat. A kérdőív kérdéseire adott válaszokból számított Cronbach-alfa teszt értékei

\begin{tabular}{|l|c|}
\hline Múködési terület & Cronbach-alfa \\
\hline Pénzügyek & 0,731 \\
\hline Termelési tényezők & 0,808 \\
\hline Termelés, szolgáltatás & 0,859 \\
\hline Marketing, kereskedelem & 0,864 \\
\hline A döntés tárgya & Cronbach-alfa \\
\hline Piaci-gazdasági & 0,598 \\
\hline Müszaki & 0,910 \\
\hline Szervezési & 0,860 \\
\hline
\end{tabular}

Müködési területenként vizsgálva a döntéshez szükséges információforrásokat, a vezetők válaszai a következöképpen összegezhetők:

Pénzügyi területen a felsorolt 48 információforrásból nyolcat használnak előszeretettel a vezetők ezek: a tervezés, kontrolling, pénzügy és számvitel, beszerzés, vezetők, szakmai lapok, internet és bankok.

A termelési tényezők területén viszonylag kevés, mindössze három olyan információforrás van, ami a vezetők véleménye szerint kiemelkedő fontosságú: a termelés, a vezetők és a tervezés információi.

A termelés és szolgáltatás területén a termelés az első, legfontosabb információforrás, majd ettől jelentősen lemaradva következik öt másik: tervezés, vezetők, értékesítés, beosztottak és a készletgazdálkodás. A többi információforrás használata elhanyagolható.

A vezetők szerint a marketing és kereskedelemi döntések igénylik a legtöbb információforrást. Az első helyen álló értékesítés után még következik tíz másik: a tervezés, kontrolling, szakmai lapok, vezetők, pénzügy és számvitel, vevők, internet, tulajdonosok, versenytársak és a készletgazdálkodás.

Az 1. ábra a vizsgált négy müködési területen az információforrások használatának gyakoriságát összegezve tartalmazza. Az ábra oszlopai azt mutatják, hogy a vezetők hány százaléka sorolta be az egyes információforrásokat a nem használt (0), a néha használt (1), a gyakran használt (2) és a mindig használt (3) kategóriákba. Az értékek a bal oldali tengelyről olvashatók le. A • (gyémánt) jel pedig azt mutatja, hogy az egyes információforrások az összes lehetséges, maximálisan adható pontszám hány százalékát kapták a vezetőktől; az értékek a jobb oldali tengelyen láthatóak. 


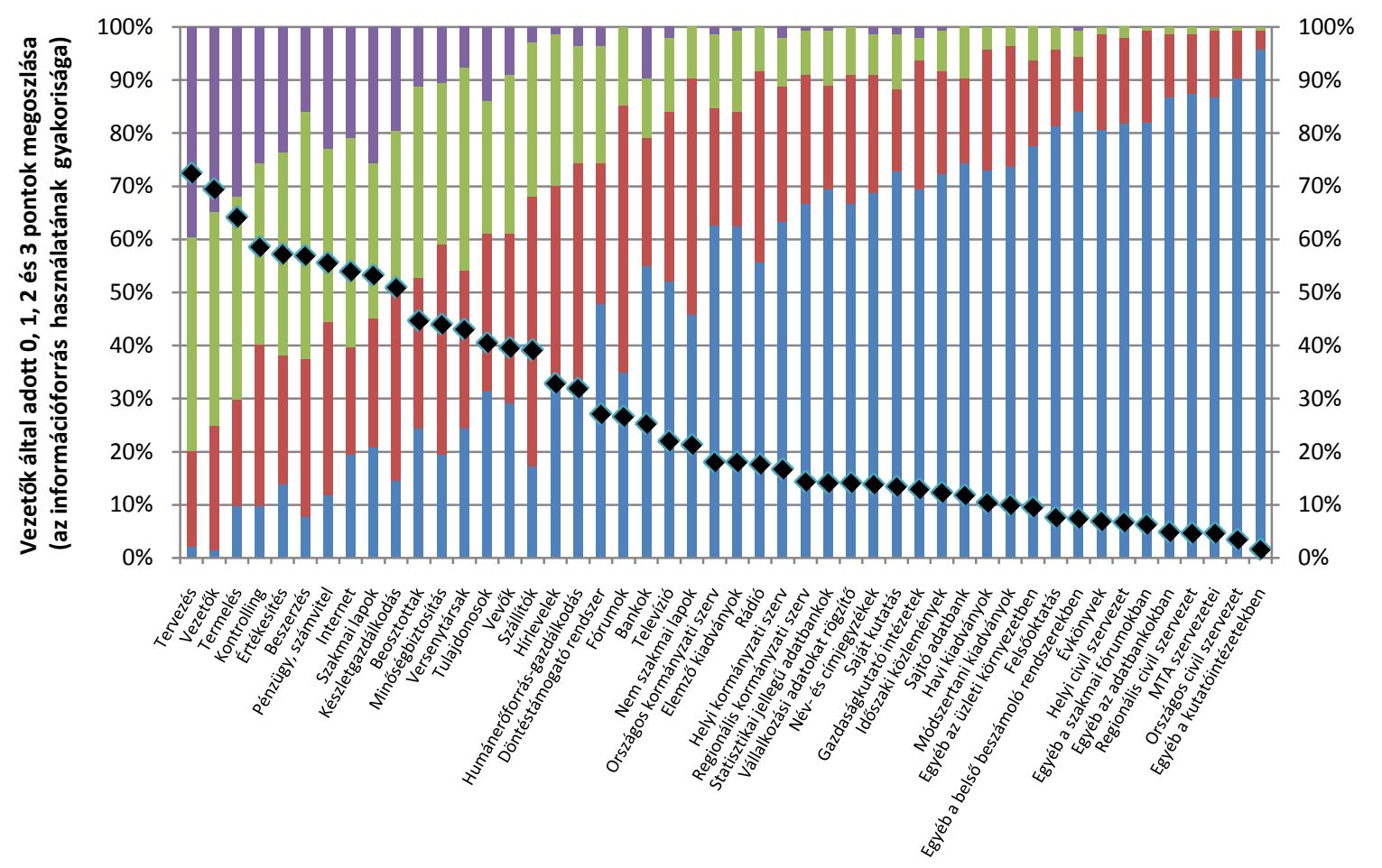

0 - Nem használt forrás 1 - Néha használt forrás 2 - Gyakran használt forrás 3 - Mindig használt forrás

Adott pontszám aránya a maximálisan adhatóhoz

1. ábra. Élelmiszeripari társas vállalkozások vezetőinek információforrásai és azok használatának gyakorisága (müködési területek szerinti vizsgálat eredményeinek összesítése)

A döntések lehetséges információforrásait a döntés tárgya szerint vizsgálva, az eredmények a következők:

A piaci-gazdasági döntések meghozatalakor hét olyan információforrás van, amit a vezetők előszeretettel alkalmaznak, ezek: a tervezés, a kontrolling, a pénzügy és számvitel, a többi vezető, a beszerzés, a szakmai lapok és az internet. A többi információforrás használata sokkal kevésbé jellemző.

A műszaki döntéseknél a leggyakrabban használt információforrások köre szükebb, a döntéshozók legtöbbször megelégszenek három információforrással: a termelési információk használata kiemelkedő, ezt követik még a vezetők és harmadikként a beosztottak.

A szervezési döntések esetében kiemelkedő fontosságú a termelés, mint információforrás, ezt követően második helyen állnak a vezetők, majd ettől jelentősen kisebb mértékben a beosztottak. A vezetők válaszai alapján a döntéshozók a szervezési döntéseknél használják a legkevesebb információforrást.

A 2. ábrán a piaci-gazdaság, müszaki és szervezési döntések információforrásainak használati gyakorisága látható összegezve. Az ábrán az oszlopokból és a bal oldali tengelyröl leolvasható, hogy a felmérésben részt vevő vezetők hány százaléka sorolta be az egyes információforrásokat a nem használt, a néha használt, a gyakran használt, illetve a mindig használt kategóriákba. A • (gyémánt) jel és jobb oldali tengely az információforrásokra adott illetve maximálisan adható pontszám arányát mutatja. 


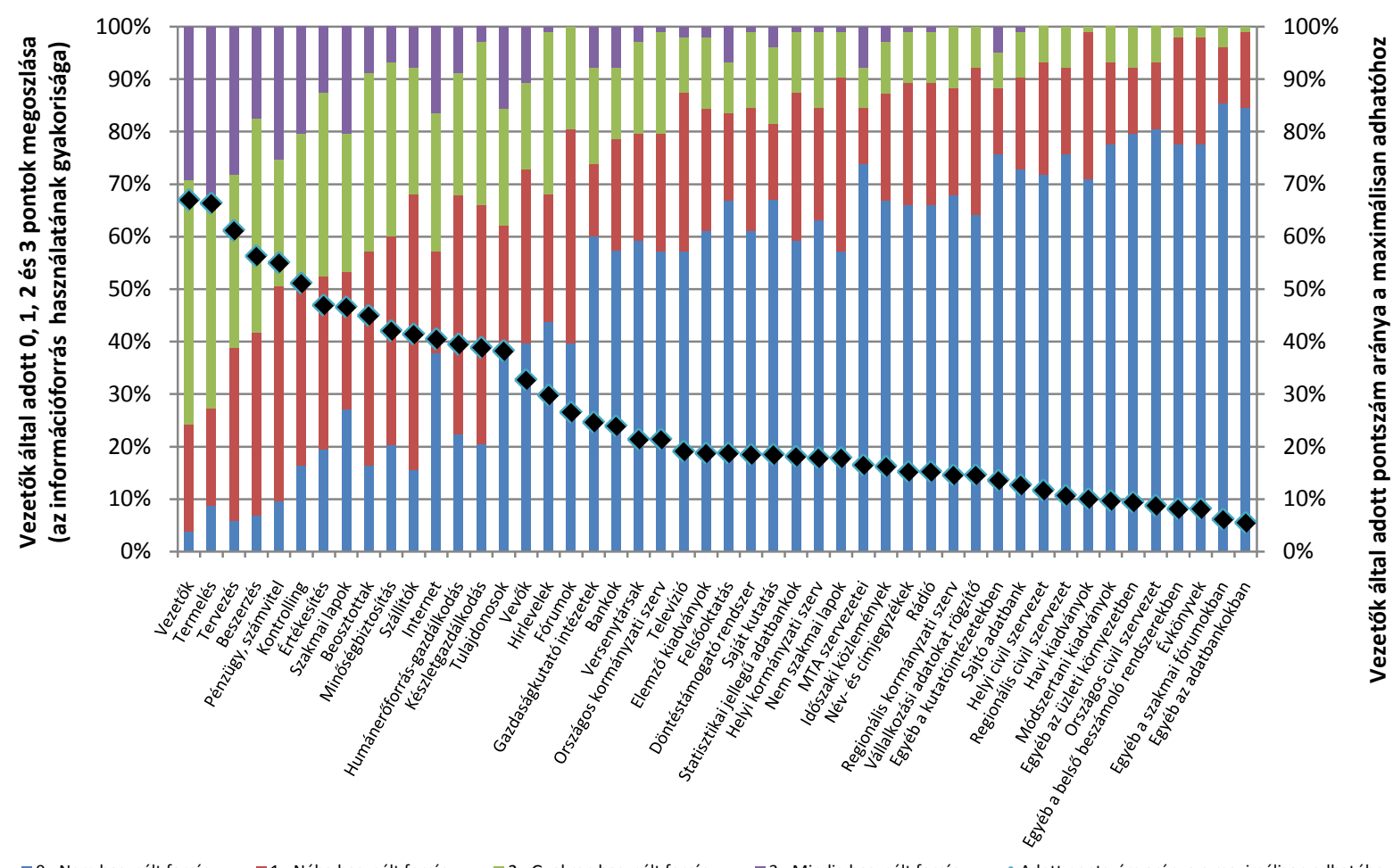

2. ábra. Élelmiszeripari társas vállalkozások vezetőinek információforrásai és azok használatának gyakorisága (a döntés tárgya szerinti vizsgálat eredményeinek összesítése)

Az előbbi 48 információforrásból képzett 10 információforrás csoportot vizsgálva kiderült, hogy a vezetők a vállalkozásban müködő belső beszámoló rendszer adataira, a körülöttük lévő emberekre, valamint a médiából származó információkra támaszkodnak leginkább a döntéseik meghozatalánál. (3. és 4. ábra) A negyedik helyen a müködési terület szerinti összesítésben az üzleti környezet, míg a döntés tárgya szerinti összesítésben a kutatóintézetek következnek. Ötödik helyen szerepelnek mindkét felmérés szerint a szakmai körök. A legkevésbé használt információforrások közé tartoznak a kormányzati szervek, a statisztikai források és az adatbankok. A kutatóintézetek szerepe nem egyértelmű az összesítés szerint: míg a múködési területek szerinti vizsgálatban ez az utolsó elötti helyen szerepel, addig a döntés tárgya szerinti vizsgálatnál a média után, negyedikként következik. Mindkét féle felmérés szerint a civil szervezetek szerepelnek utolsóként.

Az információs rendszerekre vonatkozó kérdésekre válaszoló 26 élelmiszeripari társas vállalkozás 62\%-ában használtak - a vezetők állítása szerint - valamilyen integrált vállalati információs rendszert. A felmért cégek 46\%-ában müködött egyetlen integrált információs rendszer, ami ellátta a vezetőket a döntésekhez szükséges belső információkkal. 15\%-nál müködött egynél több integrált vállalatirányítási rendszer egy, vagy több részrendszere. Ott, ahol a vállalkozáson belül többféle (nem integrált) információs rendszert is alkalmaztak, a vezetők nem tudtak egyértelmüen állást foglalni abban, hogy e rendszerek között van-e kapcsolat.

A vállalkozások felében működtettek standard, a piacon kapható rendszer a saját igényeknek megfelelően módosítva, paraméterezve. Közel ugyanennyi helyen (46\%) dolgoztak a cég megbízásából külső szakemberek által fejlesztett információs rendszerekben. Nagyon kevés volt azoknak a cégeknek az aránya, ahol saját, belső szakemberek által kifejlesztett szoftvereket használtak, mindössze a vizsgált cégek 15\%-ára volt ez jellemző. 

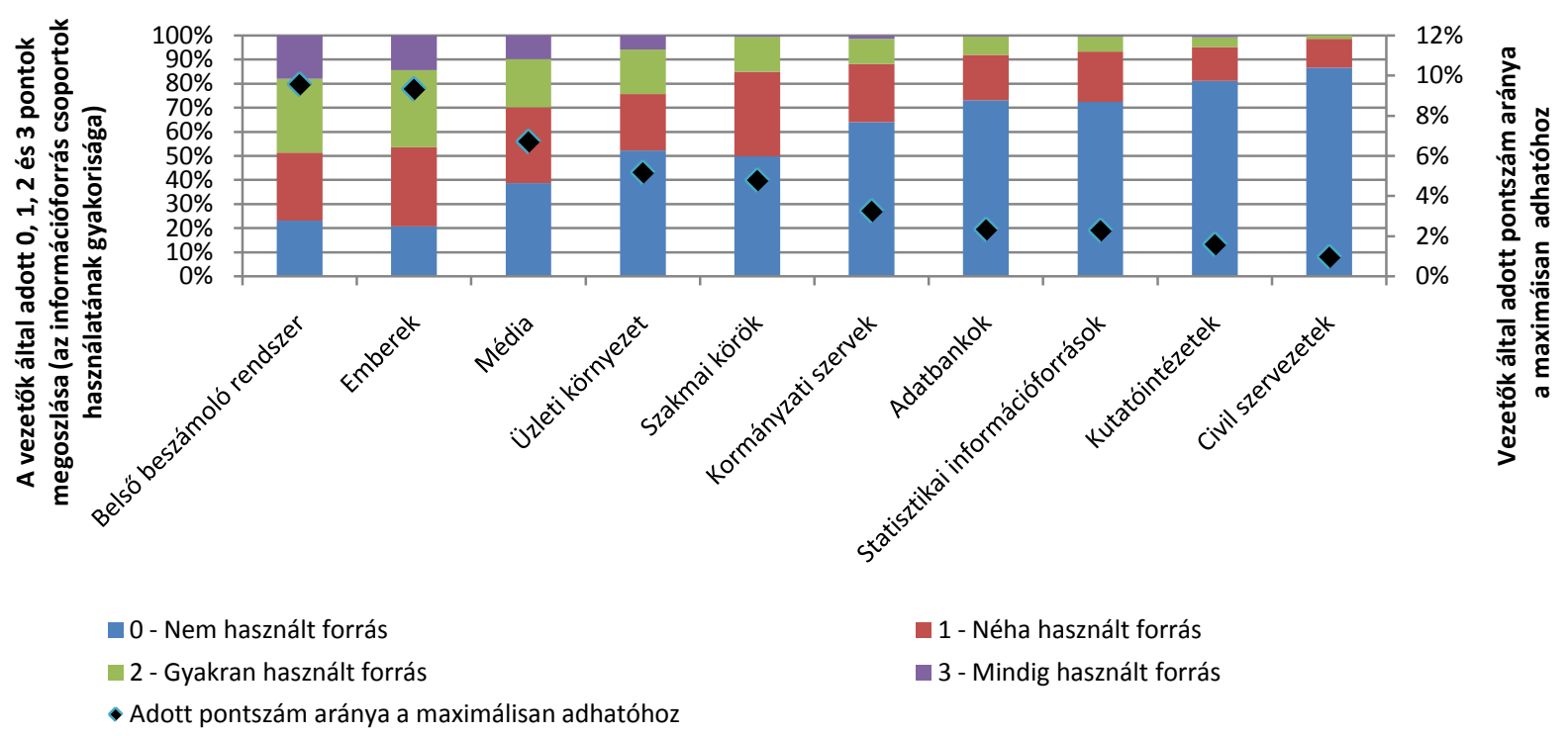

3. ábra. Információforrás csoportok használatának gyakorisága (müködési területek szerint vizsgálva, összesítés)

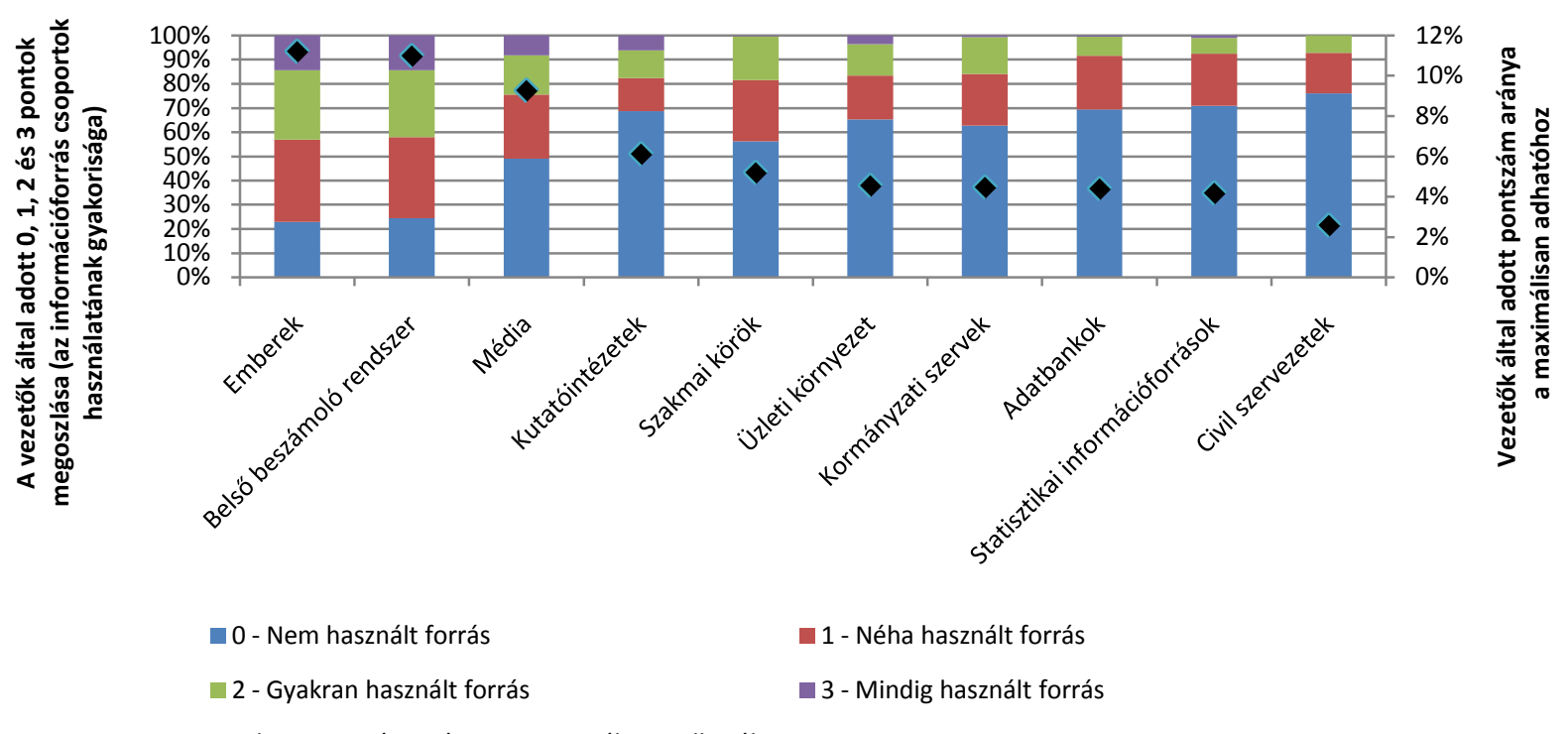

- Adott pontszám aránya a maximiálisan adhatóhoz

4. ábra. Információforrás csoportok használatának gyakorisága (döntés tárgya szerint vizsgálva, összesítés)

Az 5. ábrán látható, hogy a megkérdezett élelmiszeripari társas vállalkozásokban az információs rendszereket egyes feladatok ellátására milyen mértékben alkalmazták: A legtöbb vállalatnál könyvelési és azzal összefüggő feladatok ellátására használták a rendszereket (81\%). Második helyen a számlakészítési funkció használata állt (77\%). Gyakori volt még az információs rendszerek alkalmazása az irodai feladatok ellátására, a raktárkészlet nyilvántartására, a szállító és vevőadatok nyilvántartására. Ezeket a funkciókat a felmért cégek 73\%-ában vették igénybe. Jóval kevesebb helyen, a vállalkozások mindössze alig több, mint háromtizedében használták a számítógépes programokat logisztikai feladatok segítéséhez, illetve egyéb feladatokra (19\%).

A cégek mindössze 15\%-ában alkalmaztak információs rendszereket az erőforrások tervezéséhez. A cégek vezetőinek véleménye szerint a rendszerük támogatást nyújt a jelenlegi helyzet elemzéséhez, viszont mindössze a rendszerek 31\%-ánál van lehetőség előrejelzések készítésére. 


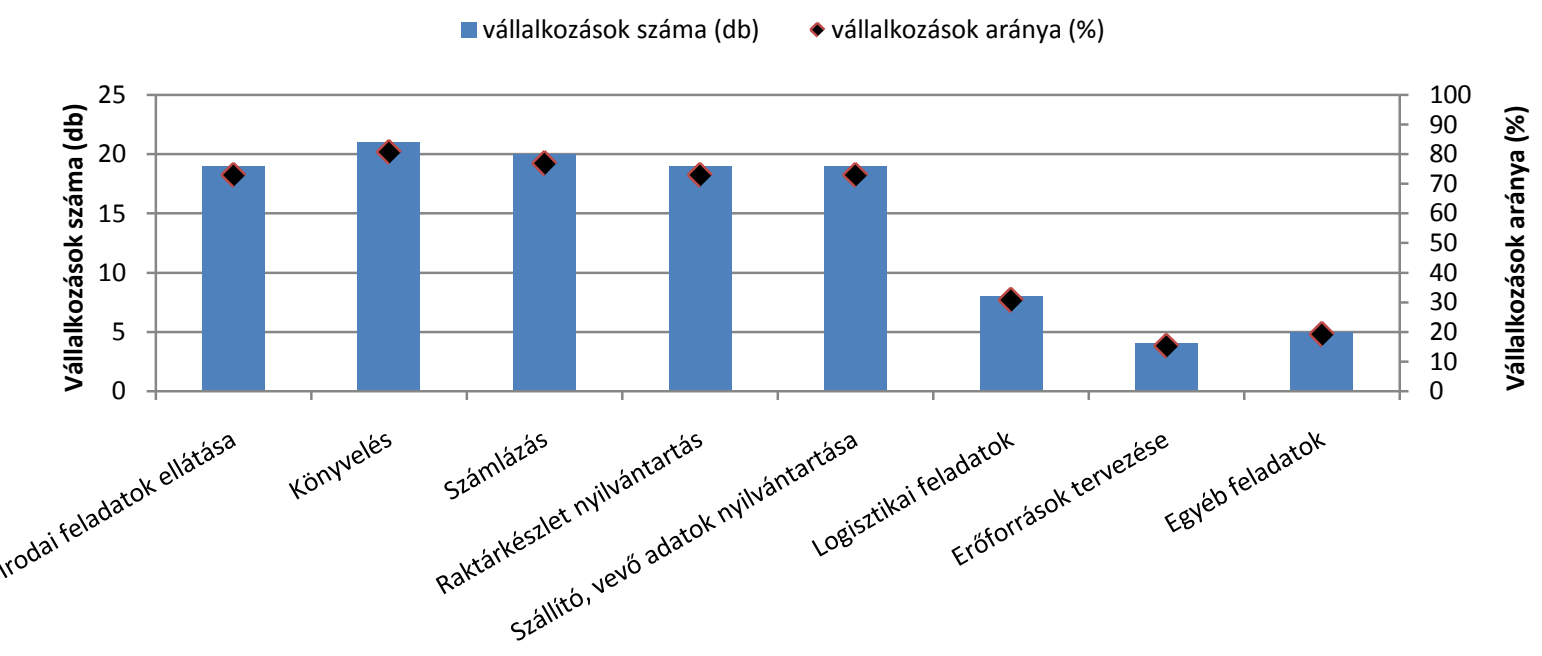

5. ábra. Az élelmiszeripari társas vállalkozások információs rendszerei által ellátott feladatok

A klaszteranalízis két, egymástól jól elkülöníthető vezetői csoportot eredményezett. A 2. táblázat a klaszterek jellemzőit mutatja. Az első klaszterbe közel fele-fele arányban tartoznak felső- és középvezetők, a felsővezetők kis túlsúlyával. A második csoportban jelentős többséget képviselnek a középvezetők.

Az első klaszter jellemzői: A vezetők az embereket használják legfőbb információforrásukként. Közel ugyanilyen mértékben támaszkodnak a belső beszámoló rendszerek adataira döntéseik meghozatalánál. Használat gyakorisága szempontjából a következő terület, ahova információért fordulnak, az üzleti környezet, a kormányzati szervek, a szakmai körök és a média. Az információforrások utolsó, legkevésbé használt körébe a statisztikai információforrások és adatbankok, a kutatóintézetek és a civil szervezetek.

A második, elsősorban középvezetőket tartalmazó klaszter jellemzői: Bár itt is az emberek és a belső beszámoló rendszerek tartoznak a leggyakrabban felhasznált információforrások közé, a klaszter tagjai általában kevesebb információforrással dolgoznak, mint az első csoportba tartozó vezetők. Szinte kizárólag csak erre a két információforrásra támaszkodnak a döntéseik meghozatala során. Ezek a vezetök nem, vagy alig használják az üzleti környezetből, a szakmai környezettől és a médiából származó információkat. Az információforrások harmadik körét, a kormányzati szervektől, a civil szervezetektől, a statisztikai kiadványokból és adatbankokból, valamint a kutatóintézetekből származó információkat ez a vezetői kör gyakorlatilag nem használja vállalati döntései során.

2. táblázat. A vezetők csoportjainak jellemzői

(0: nem használt forrás, 1: néha használt forrás, 2. gyakran használt forrás)

\begin{tabular}{|l|c|c|}
\hline Megnevezés & Klaszter 1 & Klaszter 2 \\
\hline Vezetői szint & felsö, közép & közép \\
\hline Információforrás csoport & & \\
\hline Emberek & 2 & 1 \\
\hline Üzleti környezet & 1 & $0-1$ \\
\hline Kormányzati szervek & 1 & 0 \\
\hline Civil szervezetek & $0-1$ & 0 \\
\hline Belső beszámoló rendszerek & $1-2$ & 1 \\
\hline Statisztikai információforrások & $0-1$ & 0 \\
\hline Kutatóintézetek & $0-1$ & 0 \\
\hline Adatbankok & $0-1$ & 0 \\
\hline Szakmai körök & 1 & $0-1$ \\
\hline Média & 1 & $0-1$ \\
\hline
\end{tabular}




\section{Következtetések}

A vizsgált minta a kutatásban önkéntesen részt vállaló élelmiszeripari társas vállalkozások felső- és középvezetőinek köréből állt. A vállalkozások vezetői a vártnál kisebb mértékben voltak aktívak, így az eredmények a vizsgált mintára vonatkoztathatók, azokból csupán sejteni lehet bizonyos tendenciákat.

A vezetők következetesen a belső beszámoló rendszer különböző részeiből származó adatokra, információkra támaszkodnak elsődlegesen. Emellett azonban ugyanilyen mértékben hozzák meg döntéseiket más emberektől származó információkra alapozva. Mint általában az emberekre, a DélAlföld régió élelmiszeripari vállalkozások vezetőire is hatással van a médiából származó rengeteg adat, a média csoportból származó információkat tartják a vezetők a harmadik leggyakrabban használt forrásnak. A maradék hét információforrás csoportot már csak fele akkora, vagy még kisebb mértékben tartják fontosnak a döntéseik meghozatalánál.

A belső beszámoló rendszerek és az emberek elsődlegessége, mint információforrás, összhangban áll azzal az elvárással, mely szerint egy gazdasági szervezetnél vezetőknek elsősorban a szervezet belső környezetéből származó, az onnan gyüjtött tényadatok feldolgozásából létrehozott információkra alapozott döntéseket kell hozniuk. Hiszen az adatokra, információkra alapozott döntés „,racionális”. A döntések ugyanakkor nem függetleníthetők az interperszonális kapcsolatoktól. Az emberi kapcsolatok - különösen a munkahelyen belüliek -, a formális és informális kommunikáció révén szerzett információk is jelentős hatást gyakorolnak a döntéshozókra és ezen keresztül a szervezeti döntésekre.

Az, hogy más információforrás csoportokat a vezetők ritkábban használnak, több okra vezethető vissza:

- a belső információs rendszer adataiban megbíznak és kiegészítve az emberektől kapott információval a legtöbb esetben a döntésekhez elégségesnek tartják;

- a cég belső rendszere, az emberek és a média elegendően sok információval látja el a vezetőket, nincs idejük egyéb információforrásokat felhasználni;

- előfordulhat, hogy a többi információforrás csoport használata kevésbé formális, vagy nem egyértelmü, így nem tudatosul.

Megállapítható, hogy termelő vállalkozásokról lévén szó, a legfontosabb információforrást közvetlenül a szervezet információs rendszerének termeléssel kapcsolatos, vagy ahhoz szorosabban kötődő része képezi. Ezek azonban elsősorban a tranzakció feldolgozó rendszereket, illetve az azokból nyert információkat jelentik. Olyan információs rendszerek használata, amelyek kifejezetten a döntések meghozatalának támogatására vannak felkészítve, nem jellemző azoknál az élelmiszeripari vállalkozásoknál, amelyek vezetői a kutatásban részt vettek. Ennek lehetséges oka lehet, hogy a vezetők

- nem ismerik a döntések támogatására alkalmas rendszerek képességeit;

- nem bíznak benne, különösen egy gyorsan változó gazdasági és jogi környezetben;

- nem látják értelmét a rendszerbe való beruházásnak, félnek attól, hogy nem térül meg.

Minden vizsgált vállalkozásban használnak valamilyen típusú számítógépes rendszert. A vezetők tisztában vannak az információs rendszerek használatának szükségességével. A vezetők által felsorolt, információs rendszer által ellátott feladatok alapján olyan rendszerekről van szó, amelyek alkalmasak a jelenlegi helyzet elemzésére, ugyanakkor a vizsgált cégek csupán egyharmadánál állították a vezetők, hogy a rendszerük képes elörejelzések készítésére is. Nem feltétlenül van ez így, hiszen már egy táblázatkezelő is tartalmaz olyan szolgáltatásokat, amelyek alkalmassá teszik ilyen a feladatra. Sokkal inkább arról van szó, hogy a vezetők nem ismerik az információs rendszerükben rejlö döntéstámogató képességeket.

A vezetői válaszok alapján két, egymástól jól elkülöníthető csoport figyelhető meg. Az első vezetői csoportot azok az élelmiszeripari közép- és felsővezetők alkotják, akik a döntéseikhez inkább támaszkodnak információkra, míg a másik csoportot a föként középvezetőkből álló, információforrásokat kevésbé használó vezetők alkotják. Az első csoportba tartozók szélesebb körben szerzik be a döntéshozatalhoz fontosnak tartott információkat, nem csak belső, hanem külső információforrásokat is igénybe vesznek. A második, nagyrészt középvezetőkből álló csoport jobbára 
megelégszik a vállalat rendszereiből származó belső információkkal, illetve az emberektől származó információkkal.

Az első csoport tehát a felsővezetőkre jellemző tulajdonságokat mutatja, annak ellenére, hogy a csoport tagjainak közel fele a középvezetők köréből származik: ők azok, akik a nem vagy rosszul strukturált problémákról döntenek, hosszú távú stratégiai döntéseket hoznak. Mivel ezekhez a feladatokhoz az információs rendszer egyáltalán nem, vagy csak részben nyújt támogatást, más, a szervezeten kívüli forrásokból is be kell szerezniük információkat.

A második csoport a középvezetők csoportja, bár néhány felsővezető is ide tartozik. A középvezetők általában olyan időtávú és jelentőségü kérdésekben döntenek, amelyek esetében a belső beszámoló rendszerek, kiegészítve emberektől származó adatokkal, már elegendő információt nyújtanak a döntések meghozatalához.

\section{Hivatkozások}

Berde Cs. 2003. Menedzsment a mezőgazdaságban. Debrecen. Campus Kiadó. 237 p.

Bőgel Gy., F. Ható K., Keresztes J., Salamonné H. A., Zárda S. 2002. Szervezési és vezetési ismeretek: elmélet és gyakorlat informatikusoknak. Budapest. Számalk Kiadó. 213 p.

Chikán A. 2005. Vállalatgazdaságtan. Budapest. Aula Kiadó. 576 p.

Dobay P. 2003. Vállalati információmenedzsment. Budapest. Nemzeti Tankönyvkiadó. 310 p.

Enyedi M.-né. 1997. Bevezetés a döntéselméletbe. Budapest. Ligatura Kiadó. 120 p.

Hannon, N. J. 2005. Making Data the Center of Your Information System. Strategic Finance; Oct 2005, Vol. 87 Issue 4: 55-61.

Hanyecz L. 1994. Döntéshozatal. Döntési modellek. Pécs. Janus Pannonius Tudományegyetem Egyetemi Kiadó. $168 \mathrm{p}$.

Kardos B., Szántó I., Veress A. 2007. A vezetői számvitel alapjai. Budapest. Saldó Kiadó. 280 p.

Kiszl P. 2005. Az információgazdálkodás kihívásai a globális információs gazdaság korában. Vezetéstudomány. 2005. (36. évf.) 2. sz.: 38-46.

Kövesi J., Andor Gy. 2007. Menedzsment és vállalkozásgazdaságtan. Budapest. Budapesti Müszaki és Gazdaságtudományi Egyetem - Typotex Kiadó. 324 p.

Lehota J., Horváth Á., Komáromi N., Túri Z. (2001): Marketingkutatás az agrárgazdaságban. Mezőgazda Kiadó. Budapest. 233 p.

Lönnqvist, A., Pirttimäki, V. 2006. The Measurement of Business Intelligence. Information Systems Management; Winter2006, Vol. 23 Issue 1: 32-40.

Porter, M. E., Millar, V. E. 1985. How Information Gives You Competitive Advantage. Havard Business Review 73. no. 4. July-August: 1-13.

Simon, H. A. 1982. A vezetői döntés új tudománya. Budapest. Statisztikai Kiadó. 149 p.

Szabó L. 2001. A vállalati piackutatás gyakorlata. Budapest. Perfekt Kiadó. 295 p.

Taylor, A., Farrel, St. 1995. Information Management for Business. London. Aslib. 170 p.

Wallace, T. F., Kremzar, M. H. 2006. ERP - vállalatirányítási rendszerek. Budapest. HVG Kiadó. 326 p. 